\title{
The Two-Year College LRC: Promise Deferred?
}

\section{Esther Green Bierbaum}

The library and resource needs of two-year community-junior colleges are unique: instructional programs range from academic to remedial and vocational, while the student population is equally diverse and various. Ideally, in response to these needs, the junior college "library" evolved into the community college "Learning Resources Center" (LRC). That evolution, however, has not been uniform, universal, nor even complete; indeed, the promise of the LRC has, for many institutions, been deferred. The basis for this premise may be found in three sources: the history of the two-year institution and its library; the development of standards expressing the ideal state of the LRC; and data derived from survey studies of the colleges and LRCs.

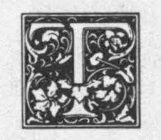

he two-year community or junior college is quintessentially an American institution. Typically community-oriented and serving a diverse population, the two-year college offers a wide range of educational opportunities, such as the first two years of baccalaureate study, terminal programs in professions and skilled trades, and postsecondary personal interest and development courses. As Marilyn Searson Lary noted: "No other type of education institution in this country is asked, indeed expected, to provide so much diversity in programs and resources for so many different demands. ${ }^{\prime \prime}$

As the two-year institution developed, the need for a way to support both teaching and learning in such a diverse environment grew. This need, and the strong influence of the new learning theories and audio and visual media that permeated post-World War II education, helped fashion the concept of a multimedia, multiservice omnium-gatherum for all print and nonprint resources. "Resources" were defined as: "all informational and learn- ing materials-regardless of their formatthat are brought together to enhance the teaching-learning process. ${ }^{\prime 2}$

Concurrently, a programmatic ideal, the "Learning Resources Program," developed and the locale for this program evolved from "library" to "media center" and then to "learning resources center," or LRC. In its ideal state, the LRC promised centralized instructional and informational collections and services tailored to the needs of the local student body and faculty.

But expressions of disquiet with the LRC concept have recently appeared in the library literature. Madison M. Mosley, calling into question the curriculum support role of the LRC, urged the adoption of a mission statement in answer to the troubling question, "Why a library? [sic] ",3 His solution was prompted by Doris Cruger Dale's study of college catalogs. She found that these public documents generally ignored the LRC and concluded that was the reason for a library. ${ }^{4}$

Dale's content analysis of catalogs reflects the thesis of this paper: for many

Esther Green Bierbaum is an Associate Professor at the School of Library and Information Science, The University of Iowa, Iowa City, IA 52242. 
two-year colleges, the LRC ideal has remained an ideal; the promise has been deferred. Three sets of sources are examined for evidence to support this premise: the literature that outlines the history of the community-junior college and library and explains what was; the standards for twoyear college libraries and LRCs that tell what might be; and statistical studies related to the standards, together with data from a recent survey, that reflect what is.

\section{The LRC concept did not spring full- blown into being with the junior- community college movement.}

\section{HISTORY}

The literature indicates that the development of the community-junior college and its programs was uneven and often uncertain. So also was the development of the college library and media resources. The LRC concept did not spring fullblown into being with the juniorcommunity college movement. Even the idea of a separate library for the junior college was not universally adopted, because the college often resulted from community necessity during the Depression and shared quarters and library collections with the local high school. In 1931, Edith M. Coulter noted that: "the greatest single factor in the educational program of the junior college [an effective library] has yet to be developed. ${ }^{\prime \prime}$

She urged colleges to secure professional library administrators and to exceed a collection size of 4,000 volumes, based on the library-related standards adopted by the American Association of Junior Colleges (AAJC) the previous year. ${ }^{6}$ But while Coulter (a library school professor) perceived the role of the library to be the creation of " assured and self-reliant users of libraries," she did not extend the concept of the collection beyond print materials-books and periodicals.

Twenty years later Harriett Genung, in sketching the developing role of the junior-community college and the result- ing changes in the library, likened the library to the hub of the institutional wheel, and laid a firm claim to the multimedia approach: "If one accepts as a basic philosophy the fact that the library's function is to implement the curriculum with all instructional materials, then the audio-visual program rightfully falls under library supervision." 7

Louis Shores supported this claim; indeed, he saw the two-year college as the epitome of his library-college and its Generic Book. ${ }^{8}$ Janiece B. Fusaro, writing in 1970 , seconded the library-college model as expanded into the "library-college media center," a place for learning and "innovations." However, she discussed staffing, administration, and nomenclature at greater length than collections and their development, access, or services.'

Kenneth W. Allen and Loren Allen were among the first to formalize the LRC concept. In their 1973 monograph, they discussed the "rationale for merging the library and audiovisual facilities into a single unit" for better support of the primary functions of the LRC, "service and instruction." 10 Yet the traditional books/ audiovisual dichotomy is implicitly recognized when the authors, in discussing the selection of nonprint, noted that "[a]udiovisual personnel are generally more knowledgeable about learning theory and nonverbal communication than librarians." 11

In 1977, California recognized the learning resources center with a set of Guidelines, which D. Joleen Bock and Leo R. LaJeunesse cited as the model for providing the three LRC components: print, nonprint, and "related instructional services." 12 These authors, in outlining steps for libraries moving into the multimedia arena, implicitly acknowledged that integrated media services were not yet a reality on most junior college campuses. They also noted that matters of bibliographical access for nonprint media, as well as their storage and circulation, were not yet settled, although: " $[w]$ ith the increased use of AV materials by students as well as faculty, many institutions have brought AV materials into the mainstream of acquisitions, cataloging, processing, circulation 
and inventory control." 13

Even so, as research in the late 1970 s suggested, the multimedia approach was not universal. Although Allen and Allen cited a 1970 Illinois survey showing that 75 percent of community-junior colleges had a unified center, ${ }^{14}$ David R. Bender's 1978 survey of 322 public institutions (resulting in 150 usable questionnaires) indicated that 65 percent of these two-year institutions followed the LRC model. ${ }^{15}$ Bender concluded that what existed was: "a movement toward the combination of print and nonprint materials in one center-a full range of instructionally related activities under the direction of one administrator."16 The responses to Bender's specific questions about shelf arrangement of materials reflected the dichotomy in practice between the junior-community library and the LRC: integrated shelving occurred in 85 percent of the LRCs, and in 57 percent of the central libraries. ${ }^{17}$

In a 1982 study specifically addressing the level of acceptance of the LRC concept, Peggy Holleman concluded, as a rationale for the finding of less than universal acceptance, that the LRC was: "dependent upon historical and political factors peculiar to the campus and upon the initiative and philosophy of the director." ${ }^{\prime 18}$ A few years later Ruth Person added a caveat: the increasingly broad sweep of the learning resources concept to include word processing and printing services may dilute library and media services and lead to "a zero sum game involving library and media services and all of the other parts of the learning resources program." 19

This confusion in role definition is mirrored in the various interpretations librarians have contributed to the literature: Coulter emphasized the support of faculty and instruction; ${ }^{20}$ Genung's aim was to teach library use; ${ }^{21}$ Bender's survey data indicated that his respondents perceived their primary role to be assisting students to learn course content; ${ }^{22}$ and Harold J. Ettelt's stated mission was to provide students with a life-skill, "the ability to cope with rapid change." ${ }^{23}$ The role of the library-LRC is, however, seldom discussed in monographic treatments of the two-year college. ${ }^{24}$

More objective assessments of the LRC are provided by the variously sponsored standards promulgated to describe and measure its role and function.

\section{STANDARDS}

The first standards for junior college libraries were adopted in 1929 by the American Association of Junior Colleges (AAJC) as part of a general set of institutional standards. They called for a minimum of "3,500 volumes," "'appropriate current periodicals," a reading room, a "trained librarian," and an annual appropriation of at least $\$ 500 .^{25}$ The Junior College Libraries Round Table of the American Library Association (ALA), meeting for the first time in June 1930, recommended quantitative standards for book collections, book budgets, and personnel that were sent to AAJC. ${ }^{26}$ The Association of College and Research Libraries (ACRL) took up the two-year college question in 1959 with "Standards for Junior College Libraries. ${ }^{\prime 27}$ While the 1968 ALA guidelines for audiovisuals in academic libraries were not directed to the two-year college, they had implications for its multimedia services. ${ }^{28}$ It was not, however, until 1971 that audiovisuals entered the arena, when AAJC, ACRL, and the Association for Educational Communications and Technology (AECT) joined forces and produced a draft standard, which became "Guidelines for Two-Year College Learning Resources Programs."'29,30 With these "Guidelines," the LRC concept stood alone in the title and incorporated the library in its definition: "Learning Resources. Includes library, audiovisual and telecommunications and encompasses instructional development functions and instructional system components. ${ }^{31}$ AAJC dropped from joint sponsorship with the publication of the 1979 supplementary set of quantitative standards by ACRL and the Community and Junior College Libraries Section of ALA. ${ }^{32}$ The most recent standards were adopted in June 1981, when ACRL and AECT issued a revision of the "Guidelines." ${ }^{\prime 3}$ The 1979 and 1981 "Guidelines"' were qualitative, not greatly differing from the 1972 version in 
statements of role and rationale.

The community-junior college has, then, not lacked for direction and guidance from the library and media professions and their national organizations in the development of the two-year college library into the LRC. However, the extent to which that guidance has borne fruit becomes clear from Raymond L.Carpenter's comparison of the LRC statistics in the Higher Education General Information Surveys (HEGIS) with the 1979 quantitative standards. ${ }^{34}$ He found that staff size, hours of service, and size of print collections (both books and periodicals) were generally below the levels of the standards, but when specific forms of visual materials were brought together: "the data ... do show that the holdings [of 'audiovisual units'] are much closer to standard than are either periodical subscriptions or books. ${ }^{\prime \prime 35}$

The LRCs, then, to an extent had adopted at least an audiovisual advocacy relative to standards for print and nonprint collections. Carpenter's conclusions regarding fiscal support for the LRC were less sanguine: "most institutions fall well below" the standard that recommends allotting seven to twelve percent of the general budget to the LRC. ${ }^{36}$ Indeed, he cites this lack of institutional support as the reason that "most libraries are below the standard for nearly all factors.",37

The final source of support for the premise of the unfilled promise of the LRC is a recent survey of two-year institutions.

\section{SURVEY FINDINGS}

In 1989 the writer surveyed sixty-six two-year college libraries or LRCs, receiving usable responses from fifty-four $(82 \%)$; thirty-eight $(70 \%)$ of the colleges were public institutions, sixteen $(30 \%)$ were private. The findings are outlined in the sections following under the headings, "Evaluation," "'Terminology," "Collections," "Bibliographic Access," and "Physical Access."

\section{Evaluation}

The responses to a question regarding institutional evaluation of the library-LRC parallel Carpenter's conclusion of with- held support and Dale's finding of lack of involvement on the part of the college administrations. As shown in table 1, only 39 percent of the public and 31 percent of the private institutions with print and nonprint collections and services are evaluated by their central administrations. The difference between public and private colleges is not statistically significant. Six of the public institutions, or 40 percent, claimed to be evaluated under the 1982 "Guidelines," and four (26 percent), under a combination of 1972, 1979, and 1982 standards. Only one private institution claimed to be evaluated under the 1982 standards; the rest used "other" measures such as "reader polls and surveys." The reader may conclude that the guidelines for LRCs have not greatly influenced the measurement of the resource programs represented in this sample.

\section{Terminology}

"Library" or "Learning resources center?" Dale describes the terminology as "still in a state of flux." ${ }^{\prime 38}$ Indeed, the confusion in terminology is reflected in the ambiguity in dealing physically with print and nonprint resources in the two-year college. Respondents report that print and nonprint are housed together in a majority $(61 \%)$ of instances, and in what 56 percent of the institutions call their "library." When format categories are housed separately, print is as equally likely to be found in a "learning resources center" as a "library," while nonprint is more often in the LRC $(60 \%)$ or the "media center" $(26 \%)$. Even when print and nonprint are separated, in 43 percent of the colleges the same person directs both sites. While the small proportion of responses from private institutions precludes a statistically

\section{TABLE 1}

LIBRARY/LRC EVALUATION BY CENTRAL ADMINISTRATION

\begin{tabular}{|c|c|c|c|c|c|c|}
\hline & \multicolumn{2}{|c|}{ Public } & \multicolumn{2}{|c|}{ Private } & \multicolumn{2}{|c|}{ Total } \\
\hline & & $\%$ & & $\%$ & $\mathrm{~N}$ & $\%$ \\
\hline Yes & 15 & 39 & 5 & 31 & 20 & 37 \\
\hline No & 21 & 55 & 10 & 62 & 31 & 57 \\
\hline $\mathrm{N} / \mathrm{R}$ & 2 & 5 & 1 & 6 & 3 & 5 \\
\hline & $\overline{38}$ & $\overline{99}$ & $\overline{16}$ & $\overline{99}$ & $\overline{54}$ & $\overline{99}$ \\
\hline
\end{tabular}


TABLE 2

FREQUENCIES OF BOOK AND AV COLLECTIONS BY RANKED SIZE CATEGORIES

\begin{tabular}{|c|c|c|c|c|c|c|}
\hline & Book Collections & N. & $\%$ & AV Collections & $\mathrm{N}$. & $\%$ \\
\hline $\begin{array}{l}\text { Descriptive Data } \\
\text { Mean } \\
\text { S.D. }\end{array}$ & $\begin{array}{l}40,747 \\
23,322\end{array}$ & & & $\begin{array}{l}5,788 \\
6,848\end{array}$ & & \\
\hline $\begin{array}{l}\text { Category Ranks } \\
\text { Small (1) } \\
\text { Medium (2) } \\
\text { Large (3) } \\
\text { Total } \\
\end{array}$ & $\begin{array}{c}\text { Size Ranges } \\
3,800-35,000 \\
35,001-65,000 \\
65,001-101,600\end{array}$ & $\begin{array}{r}26 \\
18 \\
7 \\
51 \\
\end{array}$ & $\begin{array}{r}51 \\
35 \\
14 \\
100 \\
\end{array}$ & $\begin{array}{r}\text { Size Ranges } \\
50-4,500 \\
4,501-9,000 \\
9,001-29,800\end{array}$ & $\begin{array}{r}25 \\
8 \\
8 \\
41 \\
\end{array}$ & $\begin{array}{l}61 \\
19 \\
\underline{19} \\
99 \\
\end{array}$ \\
\hline
\end{tabular}

valid conclusion, there appears to be some slight association of student body size to the term used for a multipurpose site. In the small schools (fewer than 1,000 students) the term is more apt to be "library," while LRC is favored by larger schools. Since in this sample-as in Carpenter's data-the smaller schools tend also to be private, the retention of the library designation may also reflect institutional conservatism.

\section{Collections}

Carpenter found that junior-community colleges were closer to compliance with audiovisual than book and periodical standards. This finding does not address the question of the relative emphasis placed on the two media categories in the collections. It was possible to devise a simple proportional scale of book-AV collections based on the data found in the standard directory. These data are selfreported, of course, and are not free of such inconsistencies as title/volume/item counts and ambiguous reporting of various types of visual media. However, partitioned into three size rankings as shown in table 2, they can be the basis for a good estimate of the size of book and media collections relative to collections in other institutions. The data in table 2 indicate that "compliance" with nonprint standards still means that 61 percent of the institutions fall in the small category and 19 percent in the medium, while for print collections, the figures are 51 and 35 percent, respectively.

Table 3 compares within-institution size ranks of print and nonprint collections. In thirty-four $(83 \%)$ of the institutions, the print collection ranking exceeds that of the nonprint, while in only seven $(17 \%)$ is the opposite observed. In general, then, we see a continuing relative primacy of print. Indeed, for ten colleges, the print data were listed, but not the nonprint, suggesting that the latter formats were either of insufficient number or perceived importance to submit on the directory form.

\section{Bibliographic Access}

Access to resources, both bibliographical and physical, is an important element of library standards. Bibliographical access is provided by a card catalog in $74 \%$ of the college libraries or LRCs. In $77 \%$ of the institutions, the same person is in charge of both print and nonprint cataloging; $77 \%$ currently base records for print and nonprint on AACR2 (an increase from the $62 \%$ found in a similar 1984 survey). Cataloging nonprint is more likely to be manual: for cataloging print, $76 \%$ of the respondents use a combination of bibliographic utility and original cataloging, and $20 \%$ use card services; but for non-

TABLE 3

COMPARISON OF WITHININSTITUTION RANKS OF BOOK AND AV COLLECTIONS

\begin{tabular}{lcrc}
\hline \hline Book Rank & AV Rank & N & $\%$ \\
\hline 1 & 1 & 17 & 41.4 \\
1 & 2 & 1 & 02.4 \\
1 & 3 & 3 & 07.3 \\
2 & 1 & 8 & 19.5 \\
2 & 2 & 2 & 04.9 \\
2 & 3 & 3 & 07.3 \\
3 & 1 & 0 & 00.0 \\
3 & 2 & 5 & 12.2 \\
3 & 3 & $\underline{2}$ & $\underline{04.9}$ \\
\hline
\end{tabular}


TABLE 4

CIRCULATION OF AUDIOVISUAL MATERIALS

\begin{tabular}{lccc}
\hline \hline Medium & $\begin{array}{c}\text { To Faculty } \\
\text { \%Respondents }\end{array}$ & $\begin{array}{c}\text { To Students } \\
\text { \% Respondents }\end{array}$ & $\begin{array}{c}\text { Student/Faculty } \\
\text { Circulation Ratiot }\end{array}$ \\
\hline Map & 65 & 37 & .57 \\
Filmstrip & 92 & 42 & .46 \\
Photoslide & 92 & 42 & .46 \\
16 mm. film & 85 & 22 & .26 \\
Videocassette & 98 & 54 & .55 \\
Videodisc & 33 & 11 & .33 \\
CD-ROM (text) & 9 & 4 & .40 \\
CD (audio) & 24 & 9 & .38 \\
Audiocassette & 96 & 74 & .77 \\
Phonodisc & 87 & 63 & .72 \\
Graphic & 55 & 29 & .53 \\
Object & 42 & 17 & .39 \\
Otherł & 15 & 9 & .62 \\
\hline
\end{tabular}

* Since faculty circulation apparently is universal, this datum also represents percent of institutions reporting the format in the collection. tThe higher the ratio, the greater is student access to the medium relative to faculty access.

†Film loops, computer software, reel (audio) tape, transparencies, etc.

print cataloging, 57\% employ the combination strategy, and $37 \%$ perform all original cataloging. Card production services are generally not an option. For $6 \%$ of respondents the solution is simply not to catalog audiovisuals. While the situation has improved with the wider adoption of AACR2, bibliographical access is not equally provided to print and nonprint resources.

\section{Physical Access}

Physical access is a variable situation also. While all respondents say that access is provided to both print and nonprint materials, when it comes to circulation, format and academic status matter. Save for customary restrictions on reference and periodical materials, all institutions circulate print materials to students and faculty alike. Rank, however, has its privilege when it comes to borrowing nonprint (and circulation, for these media, includes inhouse use). As table 4 indicates, sound cassettes enjoy the highest student/faculty circulation ratio (.77), with phonodiscs next (.72). At the other extreme, 16$\mathrm{mm}$ films have a low ratio of .26 , and videodiscs, .33 . The old standard media formats and the popular new formats are most frequently found in the nonprint collections, with 98 percent of respondents reporting videotapes, a format overtaking $16-\mathrm{mm}$ film. ${ }^{39}$ But student use of even the popular formats is restricted. Nonprint collections, then, are varied, but they are not uniformly accessible, either bibliographically or physically.

\section{ASSESSMENT AND FUTURE}

The history of the LRC explains what has been; the standards, what could be; the college catalog content and the HEGIS statistics analysis and the survey here reported, what is. For the most part, the concept of unified and integrated collections of teaching and learning resources has been set aside or given administration lip service without meaningful support.

What will be is in other hands-those of the administrators of the two-year colleges and of the learning resources programs and centers. The writer hopes that future literature will report an increasingly cooperative and supportive stance taken by the college administration, and an increasingly active role adopted by the LRC administration. Past and recent literature suggests that the latter eventuality will need to come first: the LRC staff must formulate and publicize a mission state-

The LRC staff must publicize a mission statement, deliver informative copy for the college catalog, become familiar with the LRC standards, and demand to be evaluated annually. 
ment, create and deliver informative copy for the college catalog, become familiar with the LRC standards, and then seekeven demand-to be evaluated annually. The central administration may be ignorant of the standards; the LRC staff cannot be and still make a claim to professional status. Only as the staff describes and exemplifies the unique role and function of the LRC will the college administration perceive and value that singularity.

Moreover, the learning resources center, as a library specialty, also needs to be more highly valued by the library and media community. ALA lists the Community and Junior College Libraries Section (CJCLS) of ACRL; but AECT does not sup- port a LRC specialty, and the Association for Library and Information Science Education (ALISE) lumps together under the heading of "Academic Libraries" its members' teaching and research interests in college and university libraries, research libraries, and LRCs.

The LRC concept is unique, an ideal rich in promise for teaching and learning through many modes and media within the embracing context of the two-year, community-oriented community-junior college. Until its proponents and its colleges find a mutual vision of mission and role, the promise seems likely to continue to be deferred.

\section{REFERENCES AND NOTES}

1. Marilyn Searson Lary, "Community/Junior College Libraries: National and International Aspects," Library Trends 33:439-40 (Spring 1985).

2. Ruth J. Person, "The Organization and Administration of Two-Year College Learning Resources," Library Trends 33:441-57 (Spring 1985).

3. Madison M. Mosley, "Mission Statements for the Community College LRC," College \& Research Libraries News 49:653-54 (Nov. 1988).

4. Doris Cruger Dale, "The Learning Resource Center's Role in the Community College System," College E Research Libraries 49:232-38 (May 1988).

5. Edith M. Coulter, "The Functions of the Junior College Library," Junior College Journal 1:481-86 (April 1931).

6. American Association of Junior Colleges, "Tenth Annual Meeting" (Atlantic City, N.J., Nov. 19-20, 1929), p.156-57.

7. Harriett Genung, "Heart of the College," Junior College Journal 24:136-46 (Nov. 1953).

8. Louis Shores, "The Library Junior College: A New and Larger Role for the Library in the Junior College," Junior College Journal 36:6-9 (March 1966); and "The Junior College Impact on Academic Librarianship," College \& Research Libraries 30:214-21 (May 1969).

9. Janiece B. Fusaro, "Toward Library-College Media Centers," Junior College Journal 40:40-44 (April 1970).

10. Kenneth W. Allen and Loren Allen, Organization and Administration of the Learning Resources Center in the Community College (Hamden, Conn.: Linnet, 1973), p.12-13.

11. Ibid., p.58.

12. D. Joleen Bock and Leo R. LaJeunesse, The Learning Resources Center: A Planning Primer for Libraries in Transition (New York: R. R. Bowker, 1977), p.3.

13. Ibid., p.6.

14. Allen and Allen, Organization and Administration, p.13.

15. David R. Bender, Learning Resources and the Instructional Program in Community Colleges (Hamden, Conn.: Library Professional Publications, 1980), p.97.

16. Ibid., p.207.

17. Ibid., p.121.

18. Peggy Holleman, "How Widely Has the Learning Resources Program Concept Been Adopted?" Community and Junior College Libraries 1:1-8 (Fall 1982).

19. Person, "The Organization and Administration," p.455.

20. Coulter, "The Functions," p.481-86.

21. Genung, "The Heart of the College," p.141.

22. Bender, Learning Resources, p.242.

23. Harold J. Ettelt, "Why Is This Library?" Community and Junior College Libraries 4:1-2 (Fall 1985). 
24. An exception is the succinct treatment by Arthur M. Cohen and Florence B. Brawer in The American Community College (San Francisco, Calif.: Jossey-Bass, 1982), p.157-60.

25. American Association of Junior Colleges, p.156-57.

26. "A Junior College 'Measuring Stick,' " Bulletin of the American Library Association 24:296-97 (Aug. 1930).

27. "Standards for Junior College Libraries," College \& Research Libraries 21:200-6 (May 1960).

28. Audio-Visual Committee of the Association of College and Research Libraries, Guidelines for Audio-Visual Services in Academic Libraries (Chicago: American Library Assn., 1968.)

29. "AAJC-ACRL Guidelines for Two-Year College Library Learning Resources Centers," College \& Research Libraries 32:265-78 (Oct. 1971).

30. "Guidelines for Two-Year College Learning Resources Programs," College \& Research Libraries News 33, no.11:305-15 (Dec. 1972) (i.e., CERL 33/7(B)); Audiovisual Instruction 18:50-61 (Jan. 1973).

31. "Guidelines," (1972), p.306.

32. "Draft: Statement on Quantitative Standards for Two-Year Learning Resources Programs," College \& Research Libraries News 40, no.3:69-73 (March 1979).

33. "Guidelines for Two-Year College Learning Resources Programs (revised)," College \& Research Libraries News 43:5-10 (Jan. 1982) (Part One); 43:45-49 (Feb. 1982) (Part Two).

34. Raymond L. Carpenter, "Two-Year College Libraries: A Comparative Analysis in Terms of the ACRL Standards," College \& Research Libraries 42:407-15 (Sept. 1981).

35. Ibid., p.412.

36. Ibid., p.413.

37. Ibid., p.415.

38. Dale, "The Learning Resource Center's Role," p.233.

39. The incidence of video formats exceeded that of $16 \mathrm{~mm}$ by 61 percent to 30 percent in forty-three California college and university libraries responding to a survey December 1985. Of these institutions, 66 percent collected audiocassettes and 72 percent, phonodiscs. From Henry J. DuBois, "No Room at the Inn: Media Collections and University Libraries," CERL News 49:530-32 (Oct. 1987).

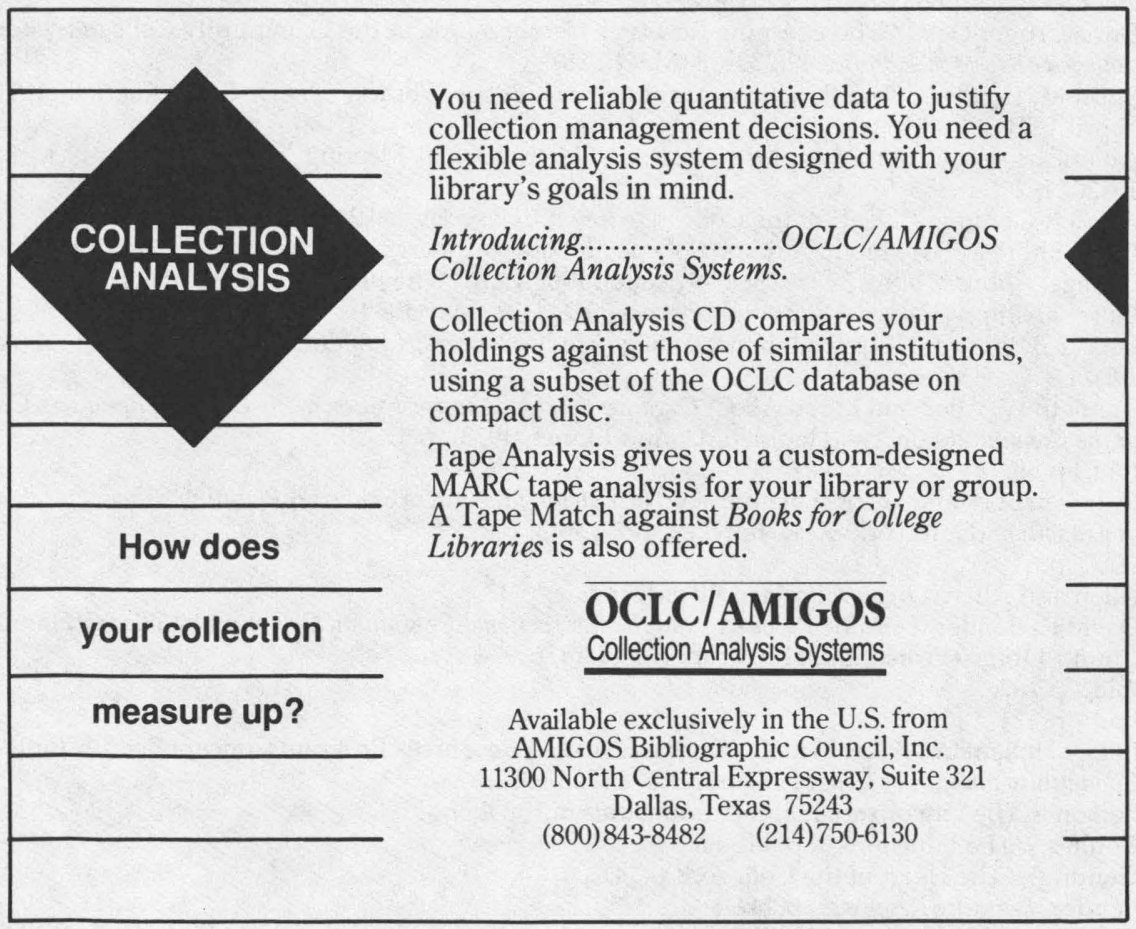

